\title{
Skin Squamous Cell Carcinoma or Other Skin Carcinomas pN2 TNM Finding v7
}

National Cancer Institute

\section{Source}

National Cancer Institute. Skin Squamous Cell Carcinoma or Other Skin Carcinomas pN2

TNM Finding v7. NCI Thesaurus. Code C88486.

Skin squamous cell carcinoma or other skin carcinomas with metastasis in a single ipsilateral lymph node, more than $3 \mathrm{~cm}$ but not more than $6 \mathrm{~cm}$ in greatest dimension; or in multiple ipsilateral lymph nodes, none more than $6 \mathrm{~cm}$ in greatest dimension; or in bilateral or contralateral lymph nodes, none more than $6 \mathrm{~cm}$ in greatest dimension. (from AJCC 7th Ed.) 